\title{
Periodic Discordance Between Vote Equality and Representational Equality in the United States
}

\author{
Sarah K. Cowan
}

New York University

Abstract: American democracy has two central values that are often in tension: vote equality, that each vote has equal influence, and representational equality, that each elected official represents equal numbers of people. The electoral standard of "one person, one vote" ensures representational equality, and that often ensures vote equality. This relationship fails, however, under certain demographic conditions, namely, when a large, non-enfranchised population resides unevenly across jurisdictions. Then, representational equality is preserved and vote equality is violated. Prior to women's suffrage, for example, western states had relatively fewer women than the remainder of the country, contributing to gross vote inequality, though rectified through extension of the franchise. Given recent high rates of immigration to some states, I ask whether the two values are in tension. I find that they are, and quantify the electoral consequences of this disjuncture at 13 House seats in 2010.

Keywords: apportionment; Supreme Court of the United States; enfranchisement

Citation: Cowan, Sarah K. 2015. "Periodic Discordance Between Vote Equality and Representational Equality in the United States." Sociological Science 2: 442-453.

Received: July 25, 2015

Accepted: August 8, 2015

Published: August 19, 2015

Editor(s): Jesper Sørensen, Stephen Morgan

DOI: 10.15195/v2.a21

Copyright: (C) 2015 The Author(s). This open-access article has been published under a Creative Commons Attribution License, which allows unrestricted use, distribution and reproduction, in any form, as long as the original author and source have been credited. (C) (i)

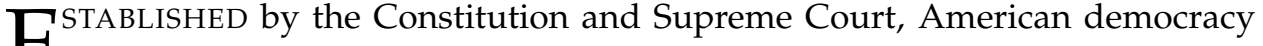

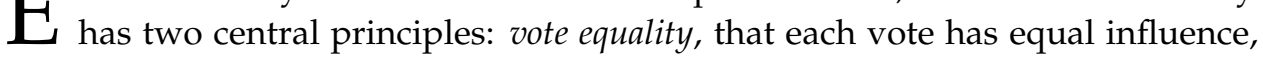
and representational equality, that each elected official represents equal numbers of people. They are realized through apportionment, which in turn influences political and economic realities, namely, the geographic and partisan distribution of House seats, public expenditures, and economic growth (Ansolabehere and Snyder 2008), the policy preferences of the median voter and politician responsiveness to given constituents, and electoral outcomes (McCarty, Poole and Rosenthal 2008; Uggen and Manza 2002; Manza and Uggen 2006; Pettit 2012).

In a series of cases during the 1960s, the Court mandated the fulfillment of representational equality, and argued that doing so would entail fulfilling vote equality. Demography, however, tells us otherwise. House seats are apportioned according to the total population, including those people who are ineligible to vote. When a large, non-enfranchised population resides unevenly across jurisdictions, the voting-eligible populations are afforded greater influence by electing representatives apportioned to the total population. For example, Illinois and Indiana are neighbors, and have similar shares of two populations that are ineligible to votechildren (23.5 percent; 24.1 percent) and felons ( 0.38 percent; 0.43 percent)—but have different shares of non-citizens (8.9 percent; 3.7 percent). All residents are counted for apportionment, and House seats are divided accordingly-Illinois with 18 and Indiana 9. Although there are fairly even numbers of residents per House seat in the two states, the numbers of eligible voters differ. To win in Illinois, a candidate must appeal, on average, to a district's 499,311 eligible voters; in Indiana, the number is 535,414. A candidate in Indiana must address more than 35,000 
additional eligible voters than a candidate in neighboring Illinois must address, and thus each eligible voter in Illinois is more influential. ${ }^{1}$

I review the legal basis for both representational and vote equality, and discuss three populations excluded previously from the franchise: women, blacks, and young adults. These examples illustrate various mechanisms that create a discrepancy that the Court overlooked. We see the greatest disjuncture between the two principles in the case of women because the female population was large, but resided unevenly across states; western states had a much smaller proportion of women than the remainder of the country. Given recent high rates of immigration to some states (Department of Homeland Security 2014), I predict that the United States is experiencing a time during which these two values are in tension. I evaluate that prediction, its effects on the House of Representatives, and routes to resolution.

\section{Establishing the Legal Standard of Representational and Vote Equality}

The Constitution's apportionment guidelines for the House of Representatives establish representational equality as a principle: "Representatives shall be apportioned among the several states according to their respective numbers...." Apportionment according to resident counts has changed only three times, and none of the changes altered the procedure fundamentally. Initially calculated by "adding to the whole Number of free Persons, including those bound to Service for a Term of Years, and excluding Indians not taxed, three fifths of all other Persons," the Fourteenth Amendment made free persons of slaves, and hence they were entered as whole persons in the count. Beginning in 1940, all Indians were counted in the apportionment base, and in 1970, military personnel, U.S. government employees, and their dependents residing overseas began being counted in their "home states" for apportionment purposes. ${ }^{2}$

Few challenges have been made to representational equality, or to the apportionment formula. The most serious attack occurred with a bill introduced before Congress in 1940 to exclude non-citizens from the apportionment base. The bill failed under arguments that apportioning according to total population was a tenet of American democracy. In an argument against the bill, Representative Emanuel Celler said, "If you strike out aliens you have parted from a principle of government upon which the fathers agreed some 150 years ago.... When we use the word persons we include all peoples" (86 Cong. Rec. 4372, 1940).

In a series of cases beginning with Baker v. Carr (1962), the Supreme Court asserted the principle of vote equality as best articulated in Gray v. Sanders's (1963) famous stricture of vote equality: "The conception of political equality from the Declaration of Independence, to Lincoln's Gettysburg Address, to the Fifteenth, Seventeenth, and Nineteenth Amendments can mean only one thing-one person, one vote." The Court went on to hear a number of cases in which one vote had greater influence than another, and it mandated representational equality to address vote inequality. ${ }^{3}$ In Burns v. Richardson (1966), however, the Supreme 
Court acknowledged that total population is neither required nor prohibited, and yet total population is the basis of nearly all apportionment (Levinson 2002) as a means to ensure vote equality and avoid infiltration of "improper influences" by those in political power (Burns v. Richardson). In principle, vote and representation equalities have a functional relationship; when representational equality is upheld, vote equality is also. The perfect juncture is often the case. The Court has not addressed definitively those occasional situations when it is not, as when a large, non-enfranchised population resides unevenly across geographic units.

This article considers the power of one vote as defined by the ratio between a jurisdiction's eligible voters and its elected officials. This definition, therefore, considers only demographic characteristics and behaviors of individuals and groupstheir size and residence. Alternative definitions could account for political behaviors. For example, voters in a low-turnout election have greater influence on the outcome of that election than they would have had if more of their peers had voted. A vote's influence might also depend on the competitiveness of the election; one could easily argue that the most powerful voter is the one who tips the scales during a tight election (Riker and Ordeshook 1968). An extensive body of literature discusses how to quantify relative voting power through development of indices such as those from Shapley and Shubik (1954), Banzhaf (1965), Deegan and Packel (1978), and Johnston (1978) (for a more recent critique of these classic indices, see Gelman, Katz, and Bafumi [2004], for a discussion of various definitions of voting power in relation to apportionment, see Fishkin [2012]). Scholars have discussed at length some of the determinants of voting power such as turnout (McDonald and Popkin 2001; Smets and van Ham 2013) and competitiveness (Abramowitz, Alexander, and Gunning 2006; McCarty, Poole and Rosenthal 2009). In choosing this definition, I follow the Supreme Court's lead by focusing on demographic characteristics, specifically avoiding discussion of individual political behaviors.

\section{Strategy of Analysis and Data}

Literature that guides the empirical analyses examines the influence of apportionment on the geographic distribution of House seats (Tienda 2002; Baumle and Poston 2004; Woodrow-Lafield 2001). The analytical strategy proceeds in two stages. First, I consider vote and representational inequalities over time. Vote inequality is measured by calculating the number of House seats per eligible voter for each state, and considering the distribution of that ratio across states for a given year. When votes are unequal, the distribution is large, meaning some states' delegations represent fewer eligible voters than others do. Representational inequality is measured similarly, but considers House seats per resident. Second, I change the apportionment base for the House by including or excluding given populations, and then simulate the distribution of House seats under various apportionment counterfactuals.

Data on enumerated enfranchised and non-enfranchised populations from 1980 to 2010 come from Michael McDonald's United States Elections Project, and the U.S. Census. McDonald's estimates begin with the voting-age population from the Census Bureau's Current Population Survey (CPS) reports. From there, he 
constructs the voting-eligible population by excluding children, non-citizens based on the CPS, and individuals who are ineligible to vote because of a criminal status based on data from the Department of Justice. He includes military and civilian personnel living overseas based on data from a number of federal agencies. There are a few exclusions not made: removing permanently disenfranchised felons based on state law, persons who are mentally incompetent to vote by state law, and those who might be ineligible to vote due to having moved to a new state after registration deadlines. These excluded populations are not large, and their inclusion would not affect results here (for more information on McDonald's measurements, see McDonald and Popkin [2001] and http://www. electproject.org).

Data prior to 1980 are from Walter Dean Burnham (as printed in McIver [2006]). These data rely on federal and state censuses, and other sources such as state lists of taxable residents. There is large variability in the quality and accuracy of the reporting, and when possible, multiple references are used. Burnham's data are the most accurate, pre-1980 estimates to date, of voting-eligible populations, but exclude some non-enfranchised populations, including those that did not fulfill taxpayer qualifications, among others (a detailed description of the data, including decision rules for inclusion, appear in Burnham [1986]).

\section{Balancing Representational and Vote Equality: Three His- torical Examples}

Throughout U.S. history, the Court's equipopulation rule has largely maintained representational equality. Vote inequality, however, has arisen periodically. Figure 1 shows box plots of House seats per 100,000 eligible voters by state-a measure of vote equality - and House seats per 100,000 residents by state-a measure of representational equality - from 1860 to 2010 (for presentational ease, outside values are excluded). A larger box indicates a wider distribution and greater inequality.

I outline three historical examples to illuminate mechanisms that create a discrepancy between representational and vote equalities. Although the examples focus on specific populations, any non-enfranchised population can contribute to a breach between these two principles. These examples were chosen because they mark significant changes to electoral law, and because they reveal various paths to resolution of the discrepancy, through enfranchisement or residential patterns.

\section{Slavery and the Black Franchise}

In pre-Civil War America, slaves were ineligible to vote, and resided heavily in a few states. Vote equality, however, was not realized fully with passage of the Thirteenth, Fourteenth, and Fifteenth Amendments. These Amendments ended slavery, expanded citizenship to all individuals born in the United States, and barred voting discrimination based on race. Although the Amendments expanded the franchise, it was contracted subsequently due to state-based voting restrictions. Even before the end of Reconstruction, southern states began to attack black voting rights with financial requirements for voting, poll taxes, literacy tests, and residency 


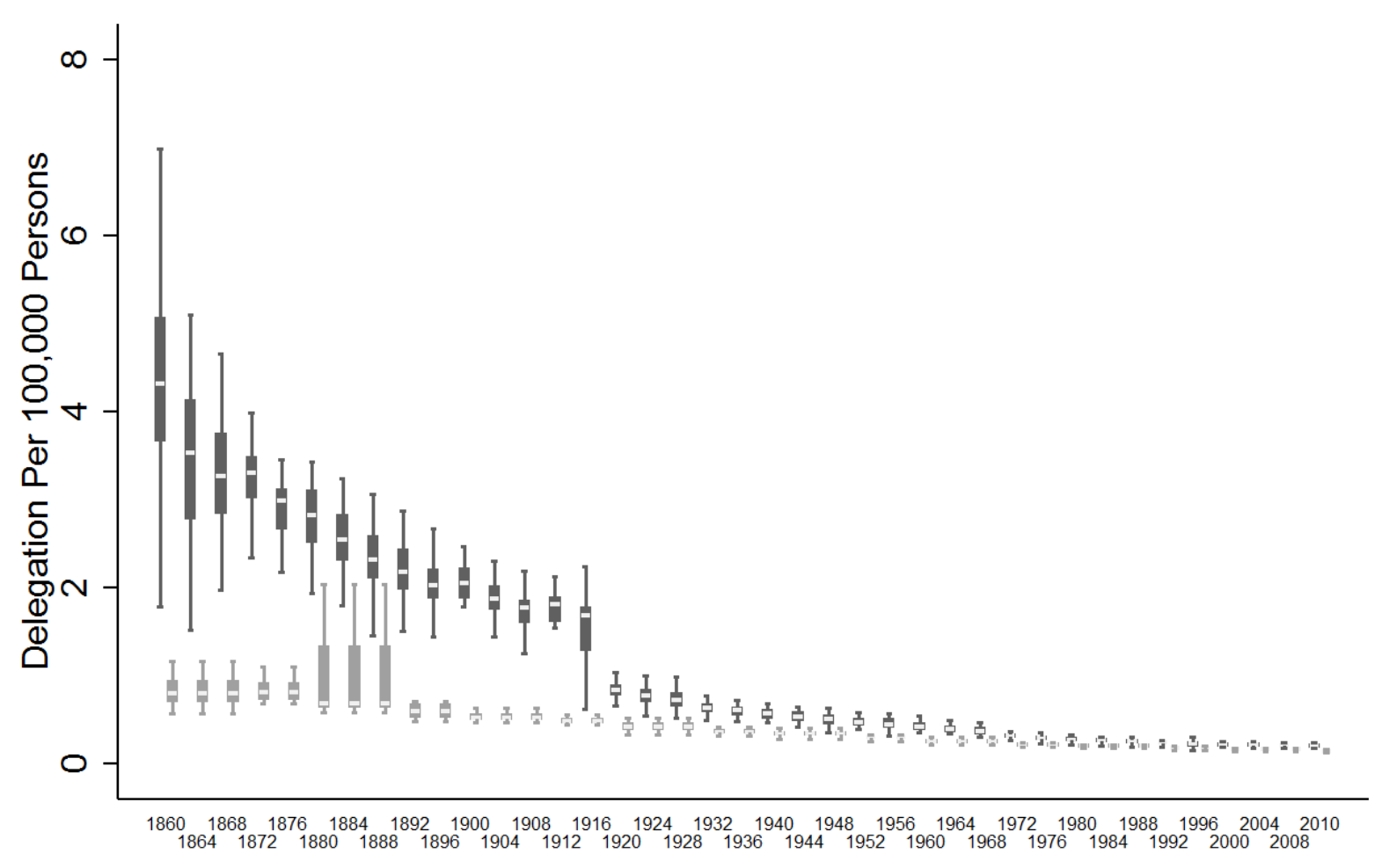

Seat Per $100 \mathrm{~K}$ Voter

Seat Per 100K Resident

Excludes outside values

Figure 1: House seats per 100,000 eligible voters by state and House seats per 100,000 residents by state from 1860 to 2010.

requirements, among others (Keyssar 2000, p. 105-11). Exacerbating vote inequality was the fact that although blacks were still not enfranchised fully, they were now counted as full persons for apportionment. Eligible (white) voters in many former slave states increased their influence because their states received more House seats due to the increased population for apportionment, while state voting restrictions ensured the same number of eligible voters. Piecemeal expansion of the franchise and elimination of the three-fifths rule maintained much of the vote inequality despite the end of slavery. Although there was some increase in vote equality following the Amendment's passage in 1865 (and that increase was partially an artifact of Burnham's data), it was not as dramatic juxtaposed to women's enfranchisement.

\section{Expanding the Franchise to Women}

At the turn of the twentieth century, women were excluded from voting in federal elections in nearly all states. Women also resided unevenly among the states; western states had fewer women as a share of the population. For example, in 
Table 1: Sources of Non-enfranchisement in the United States, 2010

\begin{tabular}{lrrl}
\hline & $\begin{array}{r}\text { Population } \\
\text { Total }\end{array}$ & $\begin{array}{r}\text { Share Total } \\
\text { Pop. }(\%)\end{array}$ & \multicolumn{1}{c}{ Designation } \\
\hline Children & & & \\
$\quad$ United States & $73,409,283$ & 23.73 & \\
Utah & 847,400 & 30.66 & Largest Share \\
California & $9,106,693$ & 24.44 & Largest Number \\
$\quad$ Vermont & 128,647 & 20.56 & Smallest Share \& Smallest Number \\
Non-Citizen Adults & & & \\
$\quad$ United States & $20,333,023$ & 6.57 & \\
California & $5,061,417$ & 13.59 & Largest Share \& Largest Number \\
West Virginia & 11,355 & 0.61 & Smallest Share \\
$\quad$ Montana & 7,468 & 0.75 & Smallest Number \\
Adults with a Criminal Record & & & \\
$\quad$ United States & $3,237,182$ & 1.05 & \\
$\quad$ Georgia & 246,996 & 2.55 & Largest Share \\
$\quad$ Texas & 473,167 & 1.88 & Largest Number \\
\hline
\end{tabular}

* Since some states allow all adults with a criminal record to vote, the smallest number and share is zero.

Source: McDonald, Michael. Turnout 1980-2010. http://www . electproject. org/. US Census Bureau. 2010 Census File. Population for the United States, Regions, States, and for Puerto Rico.

1910, California had 40 percent more men than women, and as a result, the state had the highest share of eligible voters among its residents. In contrast, New York State had 2 percent more men than women. Male New Yorkers voted on behalf of themselves, and virtually represented a nearly equal number of female New Yorkers. Californian men voted on behalf of themselves and fewer women. Hence, voting-eligible men in New York had greater influence than their counterparts in California did. During the 1910s, some states expanded the franchise to include women. The Nineteenth Amendment passed in 1920, opening the franchise to all women (Keyssar, 2000: Appendix). The enfranchisement of women reduced vote inequality, demonstrated by a decrease in variance across states between 1916 and 1920.

\section{Lowering the Voting Age}

Ratified and adopted in 1971, the Twenty-sixth Amendment lowered the voting age from 21 to 18 . Previously, four states had 18 as the minimum voting age, but the Amendment standardized the law federally. This case is similar to that of women because the franchise was expanded dramatically in one instance. Unlike women in 1920, however, people aged 18 to 20 in 1970 were distributed nearly uniformly across states. With young adults residing evenly as a share of each state's population, there was little change in the distribution of House seats due to lowering the voting age. 


\section{The Current Breach: A Story of Non-citizens}

Considering the 150-year span represented in Figure 1, the two principles of vote and representational equalities align, though imperfectly. The historical examples demonstrate that creating a breach between representational and vote inequalities requires a non-enfranchised population that is both large and resides disparately across states. The contemporary confluence of demography and electoral law creates a disjuncture between vote and representational equalities, primarily in large, immigrant-receiving states. Present sources of disenfranchisement are due primarily to age, citizenship, and criminal record. Of these populations, only the non-citizen population is both large and resides heavily in a few states, as shown in Table 1. Given these differences in residential patterns of non-enfranchised populations, I anticipate disparities in the proportion of each state's population that has the right to vote, as shown in Table 2.

If vote and representational equalities aligned, each state would have the same share of eligible voters, but this is not the case. Seventy-eight percent of Maine's population is eligible to vote, in comparison to only 61 percent of California's population. All Californians, however, whether eligible to vote or not, are counted for apportionment, giving those who are enfranchised more influence on House elections than enfranchised Mainers have. Excluding non-citizens from the franchise causes the greatest distance between the democratic values of vote and representational equalities. Simulating various apportionment scenarios measures the marginal contribution of each population in creating this distance, and the electoral magnitude of the distance. Table 3 outlines seats lost and gained according to four apportionment scenarios, excluding in the resident count minors, adults with criminal records, non-citizen adults, and all non-enfranchised populations. I apportion according to the method of Equal Proportions, which has been used to determine congressional apportionment since 1940 (for details on the method see Schmeckebier 1941). Comparing across the scenarios demonstrates that relative to children and felons, non-citizen adults have by far the greatest influence on the geographic distribution of House seats, affecting nine seats; children affect five and adults with criminal records affect two. Excluding all non-enfranchised populations from the apportionment base affects 13 House seats. Enfranchised residents in Florida, Georgia, Texas, and California elect representatives on behalf of their non-enfranchised populations, especially non-citizens, and therefore are the beneficiaries of vote inequality.

\section{Addressing Contemporary Vote Inequality}

The United States is experiencing vote inequality and therefore a discrepancy between the two principles of vote and representational equalities, due primarily to the size and residential patterns of the non-citizen population. The historical examples indicate the democratic principles can be reconciled if either the franchise is expanded, as in the case of women, or non-citizens reside more uniformly across states, as in the case of young adults. The former can be legislated, but the latter cannot. 
Table 2: Percent of Total Population that is Eligible to Vote, 2010

\begin{tabular}{lc}
\hline & Percent \\
\hline Ten States with Highest Percentage & \\
Maine & 78.04 \\
Vermont & 77.95 \\
West Virginia & 77.92 \\
North Dakota & 76.74 \\
Montana & 76.64 \\
New Hampshire & 75.87 \\
Pennsylvania & 75.24 \\
Ohio & 74.20 \\
Wyoming & 73.91 \\
South Dakota & 73.75 \\
Ten States with Lowest Percentage & \\
Idaho & 68.47 \\
Illinois & 68.44 \\
New York & 67.66 \\
Georgia & 66.63 \\
New Jersey & 66.26 \\
Arizona & 65.97 \\
Nevada & 64.96 \\
Utah & 64.38 \\
Texas & 61.57 \\
California & 61.38 \\
United States & 70.40 \\
\hline
\end{tabular}

Source: McDonald, Michael. Turnout 1980-2010. http://www. electproject.org/. US Census Bureau. 2010 Census File. Population for the United States, Regions, States, and for Puerto Rico.

Expansion of the franchise could occur through either decreased time to naturalization or more radically by allowing non-citizens to vote. The United States has a long history of extending voting rights to non-citizens; as many as 35 states have permitted alien suffrage (Keyssar 2000). Non-citizens have had few contemporary opportunities to vote, as the election in 1928 was the first federal election in which only citizens took part (see Harper-Ho 2000 for a historical and legal analysis). A few local jurisdictions allow non-citizens to vote in state and local (e.g., school board and city council) elections, but non-citizens are largely excluded from the franchise, and there is no reason to believe that will change. Non-citizens are, however, changing residential patterns. Twenty-five million people immigrated to the United States between 1980 and 2000, tripling the immigrant population. Many settled in states without established immigrant communities. By 2000, one-third of immigrants lived outside established immigrant states because of both internal migration and direct transplants from overseas to these "new immigrant gateways" (Singer 2004; Fortuny, Chaudry and Jargowsky 2010). With this geographic redistribution, the case of non-citizens would transition from being a case akin to women-a non- 
Table 3: 2010 Apportionment Based on 4 Exclusion Scenarios

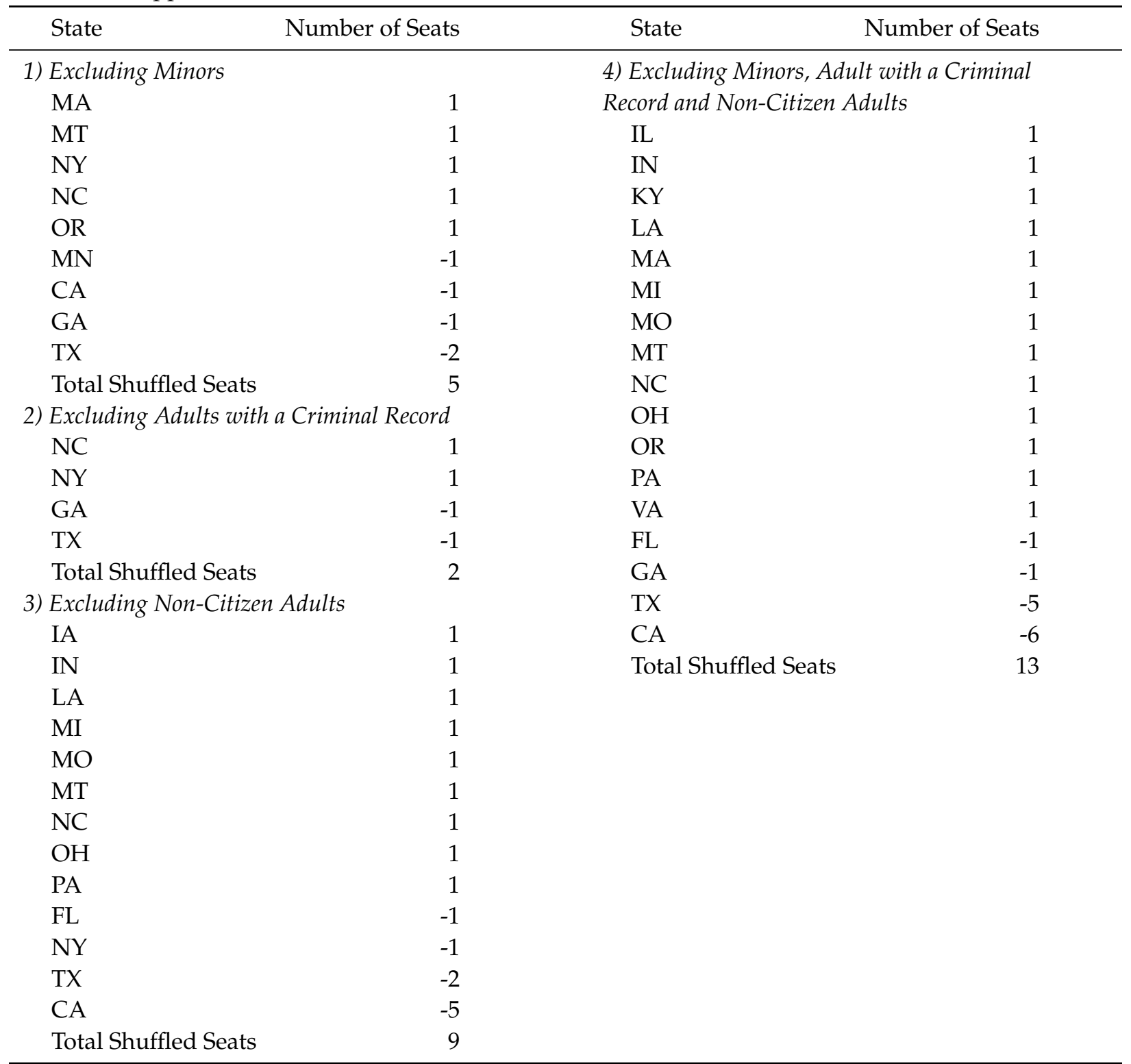

Source: McDonald, Michael. Turnout 1980-2010. http://www. electproject.org/. US Census Bureau. 2010 Census File. Population for the United States, Regions, States, and for Puerto Rico.

enfranchised population distributed unevenly across states-to one more akin to young adults—a non-enfranchised population distributed evenly across states.

\section{Conclusion}

When a large population that is ineligible to vote resides unevenly across states, American democracy cannot ensure both that legislators represent equal numbers 
of people and that votes weigh equally. Discordance then develops between representational and vote equalities. In some states, a small portion of the population would be eligible to vote, and this portion would have greater influence on choosing its representatives than voters in states in which a large portion of the population is eligible. American electoral law and practice privilege representational equality, hence when there exists disjuncture between these principles of equality, representational equality is maintained and vote equality is violated. A disjuncture can be reconciled through more even residential patterns of those ineligible to vote, or through expansion of the franchise.

A disjuncture of this nature changes American elections. Thirteen House seats are currently apportioned due to voting-ineligible populations, and most are due to the demography of non-citizens. Hence, the House is more highly representative of immigrant-receiving states, especially California, than it would be were apportionment according to eligible voting populations. Disjunctures occur periodically, with inevitable electoral, partisan, and financial consequences.

In addition to electoral consequences, a disjuncture has procedural and theoretical concerns. Choosing apportionment according to resident counts, as it is done now, introduces a source of vote inequality absent in other possible apportionment methods (e.g., apportioning according to eligible voter populations, hence upholding vote equality). This vote inequality stems from the population size and residential patterns of non-enfranchised people, ostensibly something that has nothing to do with elections but nonetheless exercises a peculiar form of electoral influence. Although apportioning according to eligible voters ensures vote equality, it does so at the expense of having residents who are unrepresented, neither actually nor virtually, and yet who are subject to American law. Apportioning according to resident counts ensures that residents have, at least numerically, equal access to representatives. Who is counted for apportioning elected officials, and who has the right to elect those officials, are expressions of inclusiveness (Tienda 2002). These questions are at the core of democracy-the nature of representation, the boundaries of community, and the rights and responsibilities of complete membership. The Supreme Court assumed that maintaining representational equality leads to vote equality, but this inquiry shows that this formula does not always hold. By default, not intent, representational equality is privileged, and vote inequality can occur with consequences for the geographic distribution of legislative seats, the elections to those seats, and the subsequent distribution of public resources. The Court will soon hear a case that challenges the equipopulation rule (Evenwel v. Abbott, No. 14-940) for state and local voting districts, with the potential for the logic to extend to congressional apportionment. ${ }^{4}$ The legal and demographic reality is that the Court will have to choose between vote and representational equalities, with its attendant consequences for American political life.

\section{Notes}

1 Vote inequality in each state is also substantial given the uneven residential patterns of non-enfranchised populations. Inequality within states is outside the scope of this inquiry, but the mechanisms work similarly. 
2 Franklin v. Massachusetts (1992) questioned whether and how overseas personnel of the Department of Defense would be apportioned. The Court voted unanimously in favor of counting the personnel as residents of their home state of record.

3 As in Reynolds $v$. Sims (1964), among others, "Whatever the means of accomplishment, the overriding objective must be substantial equality of population among the various districts, so that the vote of any citizen is approximately equal in weight to that of any other citizen in the State."

4 At least one case, Garza v. County of Los Angeles (1990), extended logic from federal to local districts. The Ninth Circuit drew on logic from Wesberry $v$. Sanders regarding congressional districting to address malapportionment for the Los Angeles City Council.

\section{References}

Abramowitz, Alan I., Brad Alexander, and Matthew Gunning. 2006. "Incumbency, Redistricting, and the Decline of Competition in US House Elections." Journal of Politics 68(1):75-88. http://dx.doi.org/10.1111/j.1468-2508.2006.00371.x

Ansolabehere, Stephen and James Snyder. 2008. The End of Inequality. New York, NY: Norton.

Banzhaf, John F. 1965. "Weighted Voting Doesn't Work: A Mathematical Analysis."Rutgers Law Review 19(2):317-43.

Baumle, Amanda K, and Dudley L. Poston. 2004. "Apportioning the House of Representatives in 2000: The Effects of Alternative Policy Scenarios." Social Science Quarterly 85:578-603. http://dx.doi.org/10.1111/j.0038-4941.2004.00234.x

Burnham, Walter D. 1986. "Those High Nineteenth-Century American Voting Turnouts: Fact or Fiction?" The Journal of Interdisciplinary History 16(4):613-44. http: //dx . doi .org/10 . $2307 / 204538$

Deegan, E. W. Packel. 1978. "A New Index of Power for Simple n-person Games." International Journal of Game Theory 7:113-23. http://dx . doi .org/10.1007/BF01753239

Fishkin, Joseph. 2012. "Weightless Votes." The Yale Law Journal 121:1888-1910.

Fortuny, Karina, Ajay Chaudry and Paul Jargowsky. 2010. "Immigrant Trends in Metropolitan America, 1980-2007." The Urban Institute.

Gelman, Andrew, Jonathan N. Katz, and Joseph Bafumi. 2004. "Standard Voting Power Indexes Do Not Work: An Empirical Analysis." British Journal of Political Science 34(4):65774. http://dx.doi.org/10.1017/S0007123404000237

Harper-Ho, Virginia. 2000. "Noncitizen Voting Rights: The History, the Law and Current Prospects for Change." Law and Inequality: A Journal of Theory and Practice 18:271-322.

Johnston, R. J. 1978. "On the Measurement of Power: Some Reactions to Laver." Environment and Planning A 10:907-14. http://dx.doi.org/10.1068/a100907

Keyssar, Alexander. 2000. The Right to Vote: The Contested History of Democracy in the United States. New York, NY: Basic Books.

Levinson, Sanford. 2002. "One Person, One Vote: A Mantra in Need of Meaning." North Carolina Law Review 80:1269-1298.

Manza, Jeff and Christopher Uggen. 2006. Locked Out: Felon Disenfranchisement and American Democracy. New York, NY: Oxford University Press. http://dx.doi.org/10.1093/ acprof : oso/9780195149326.001.0001

McCarty, Nolan M., Keith T. Poole, and Howard Rosenthal. 2008. Polarized America: The Dance of Ideology and Unequal Riches. Cambridge, MA: MIT Press. 
McCarty, Nolan, Keith T. Poole, and Howard Rosenthal. 2009. "Does Gerrymandering Cause Polarization?" American Journal of Political Science 53(3):666-80. http://dx. doi .org/10. $1111 / \mathrm{j} .1540-5907.2009 .00393 . x$

McDonald, Michael P. and Samuel L. Popkin. 2001. "The Myth of the Vanishing Voter." American Political Science Review 95:963-74. http://www . jstor .org/stable/3117725

McIver, John P. 2006. "Voter Turnout in Presidential Elections, by State: 1824-2000." Table Eb62-113 in Historical Statistics of the United States, Earliest Times to the Present: Millennial Edition, edited by Susan B. Carter et al. New York, NY: Cambridge University Press.

Pettit, Becky. 2012. Invisible Men: Mass Incarceration and the Myth of Black Progress. 1st ed. New York, NY: Russell Sage Foundation.

Riker, William H. and Peter C. Ordeshook. 1968. "A Theory of the Calculus of Voting." The American Political Science Review 62(1):25-42. http://dx . doi .org/10. 2307/1953324

Schmeckebier, Laurence Frederick. 1941. Congressional Apportionment. Washington DC: Brookings Institution Press.

Shapley, L. S. and Martin Shubik. 1954. "A Method for Evaluating the Distribution of Power in a Committee System." American Political Science Review 48(3):787-92. http: //dx.doi.org/10.2307/1951053

Singer, Audrey. 2004. The Rise of New Immigrant Gateways. Washington DC: Brookings Institution Press.

Smets, Kaat and Carolien van Ham. 2013. "The Embarrassment of Riches? A Meta-Analysis of Individual-Level Research on Voter Turnout." Electoral Studies 32(2):344-59. http: //dx.doi.org/10.1016/j.electstud.2012.12.006

Tienda, Marta. 2002. "Demography and the Social Contract." Demography 39:587-616. http://dx.doi.org/10.1353/dem.2002.0041

Uggen, Christopher and Jeff Manza. 2002. "Democratic Contraction? The Political Consequences of Felon Disenfranchisement in the United States." American Sociological Review 67:777-803. http://dx.doi.org/10.2307/3088970

U.S. Congress. Congressional Record. 76th Congress. HR 456. April 11, 1940. Pt. 4372.

U.S. Department of Homeland Security. Office of Immigration Statistics. 2014. 2013 Yearbook of Immigration Statistics. Washington, D.C.: U.S. Government Printing Office.

Woodrow-Lafield, Karen A. 2001. "Implications of Immigration for Apportionment." Population Research and Policy Review 20:267-89. http://dx.doi.org/10.1023/A: 1011890722111

Acknowledgements: Andy Katzman provided support and critically important feedback, as usual.

Sarah K. Cowan: Department of Sociology, New York University. E-mail: sarahkcowan@nyu.edu. 